\author{
Aleksandra Bergier \\ Faculty of "Artes Liberales" \\ University of Warsaw
}

\title{
Contemporary Slavery and the Struggle for Self-Determination: The Case of the Guaraní People from the Bolivian Chaco
}

\section{Introduction}

T The Guaraní, an indigenous people who inhabited a large part of the Bolivian Chaco region, for a long time were able to resist the Spanish colonization and it was not until 1892 that they were defeated by the Bolivian republican army in the battle at Kuruyuki (IACHR 2009: 24).

The massacre, in which the Guaraní sustained heavy casualties, led to their enslavement. Men, women and children were taken as prisoners and forced to serve as laborers on haciendas (Pifarré 1989: 386-399).

The conquerors received significant amounts of land from the Bolivian state; as a consequence, large latifundia in the Bolivian Chaco were established. Due to their forced introduction as semi-slaves to these estates, the Guaraní became totally dependent on their oppressors. But most importantly, they were deprived of their land and their association with other communities, thus losing their cultural heritage and their own forms of social and economic organization, which, in turn, led to the destructuring of their identity (IACHR 2009: 24-25, 27).

The Ombudsman of Bolivia defines the servitude as unpaid service and obligatory labor, originating in debts acquired through deceitful procedures, with coercive labor relations as a consequence. The semi-slavery is the obligation to work with the objective of paying off the accumulated debt, an obligation frequently inherited by offspring. The principal components of semi-slavery are: servitude, exploitation of labor and repressive labor, in many cases involving the use of physical violence and loss of liberty (Ombudsmen of Bolivia 2006: 12). The system of servitude and debt bondage that has existed in the aforementioned zones for many decades has, as one of its causes, the illiteracy of the population (the adults in particular). Due 
to this fact, the indigenous communities are unaware of their rights and are unable to exercise control over the debt books owned by the bosses. As a result, it is the owner who defines the schedules, forms of payment, frequency of the arrangements, administration of the advances, etc. Thus, the lack of knowledge of human rights and the failure to exercise the right to education are the primary factors that have impeded the amelioration of the situation (Ombudsmen of Bolivia 2006: 43).

Currently, there are 320 Guaraní communities in the Bolivian Chaco. The Guaraní political organization is composed of capitanías, a structure that represents the interests of community members. The maximum authority is the Mburuvisa Guasu (Great Captain), who has a group of advisers. Each community also has a Mburuvisa (Captain) who is accompanied by advisers (ILO 2005: 50). In 2006 it was estimated that approximately 600 families of the native Guaraní were still living in conditions of captivity and forced labor on the various estates of the Chaco (Ombudsmen of Bolivia 2006: 1823). Although there are no current estimates, it is possible to assume that these numbers have decreased considerably over the last few years due to application of agrarian legislation and other measures adopted to eradicate servitude and forced labor.

\section{Access to land and territory and the initiatives undertaken to resolve the situation of servitude and forced labor in the Chaco}

The implementation of agrarian reform, initiated in 1953, was limited to the Andean region of Bolivia and had little impact on the lives of indigenous peoples of the lowlands. In fact, it further strengthened the economic and political power of the estate owners in the Chaco region (IACHR 2009: 25).

Over the last decade there have been significant attempts to apply specific agrarian laws and procedures in order to eradicate the servitude, liberate the Guaraní people and facilitate the reconstitution of their ancestral territory. In November 2006 the Law of Communal Reorganization of Agrarian Reform No 3545 was approved. The norm introduces the distribution of land to those indigenous peoples that do not possess sufficient land or require additional areas to complement their territory. The non-fulfillment of the socio-economic function is incorporated as the instrument of restitution of farming properties, allowing for the expropriation of the land in order to donate it to those indigenous and/or original peoples that lack sufficient territories (Stavenhagen 2009: 9). Furthermore, the Supreme Decree 29215 (promulgated in November 2007) establishes that the existence of servitude 
in a specific property is a cause for non-fulfillment of the socio-economic function (CEJIS 2012).

Article 2 of the Political Constitution of the State (PCS), which was approved in Bolivia on January 25, 2009, establishes the right of the original peasant indigenous nations and peoples to consolidation of their territorial entities, given their pre-colonial existence and prior control of these territories. Likewise, the PCS grants the indigenous peoples with the right to self-determination and territoriality (Art. 30 II-4), as well as to the collective ownership of land and territories (Art. 30 II-6). Furthermore, the Bolivian Magna Carta prohibits the existence of large estates (latifundios), as well as double land ownership, due to their being contrary to the collective interest and the development of the country. The large estate (latifundio) is understood as i) an unproductive ownership of the land that does not fulfill the socio-economic function; ii) the exploitation of the land that applies a system of servitude, semi-slavery or slavery in terms of labor relationship; and (iii) the property which exceeds the maximum area which in no case may exceed 5,000 hectares (Art. 398). Article 15, paragraph V affirms that no one shall be subject to servitude or to slavery and prohibits all forms of forced labor or other analogous means of exploitation which forces a person to render services without his or her consent and just retribution (PCS 2009).

Over the last 20 years there have been many initiatives with the objective of resolving the servitude and forced labor situation, undertaken by various governments, as well as by indigenous and civil society organizations (Ombudsman of Bolivia 2006: 27-37). These initiatives have also included the participation and visits of international human rights organizations' representatives such as Inter-American Commission on Human Rights, International Labour Organization, United Nations Permanent Forum on Indigenous Issues and Special Rapporteur on the Rights of Indigenous Peoples. On several occasions, these commissions have denounced human rights violations of the Guaraní people by the estate owners in the Bolivian Chaco. They have also conducted impartial studies and published numerous reports about the situation of the captive Guarani families ${ }^{1}$.

It is especially worth noting that the highest authority of the Guaraní people in Bolivia - the Guaraní People Assembly (Asamblea del Pueblo Guaraní) has been struggling since the early 1990s to reconstitute their

\footnotetext{
1 See International Labour Organization, Enganche y Servidumbre por Deudas en Bolivia. Ginebra: 2005; United Nations Permanent Forum on Indigenous Issues. Mission to Bolivia. Report and Recommendations. N.p. 2009; Inter-American Commission on Human Rights (IACHR). Captive Communities: Situation of the Guarani Indigenous Peoples and Contemporary Forms of Slavery in the Bolivian Chaco. N.p. 2009; Stavenhagen, Rodolfo. Report of the Special Rapporteur on the Situation of Human Rights and Fundamental Freedoms of Indigenous People. Mission to Bolivia. N.p. 2009.
} 
territory and liberate the captive communities. Among the most significant actions undertaken, is the land claim within the procedure of clearing title provided for by the agrarian laws. This progress was possible due to the creation of a new category of collective property of the indigenous peoples, the Community Land of Origin (Tierras Comunitarias de Origen or TCO) (Ombudsman of Bolivia 2006: 31-32).

As a result of these initiatives, the authorities and leaders of the Guaraní people who carried out the process of clearing title had to face violent resistance brought about by the estate owners and ranchers in the zone, armed and organized in "defense committees". In 2008 these entities carried out actions to impede the entry of agrarian authorities in order to paralyze the work of clearing title (IACHR 2009: 37) and any other intervention aimed at putting an end to their traditional way of life, based on the forced labor of the indigenous people.

The violence escalated on the $13^{\text {th }}$ of April 2008 when a commission formed by the Vice-Minister of Lands, agrarian authorities, the Guaraní of the APG and some journalists left the village of Camiri in order to organize a reunion in the community of Itakuatía in the zone of Alto Parapeti, with the objective of discussing the status of the process of clearing title. Approximately 500 Guaranís were about to participate in this extraordinary assembly. Having arrived at Cuevo, the convoy was detained and brutally attacked by a roadblock formed by the inhabitants of the village and the ranchers of the zone. Members of the group were beaten, some of them were tortured and even threatened with death (Égido \& Bergier 2010: 75). Nowadays, the Guaraní can appreciate the results of their sacrifice, given that their legal and political strategy brought about favorable verdicts and the reversion of numerous haciendas which were subsequently occupied by the indigenous communities.

The process of clearing title under the agrarian legislation has undoubtedly benefited many indigenous families and has contributed to the reconstitution of their ancestral territory. Nevertheless, the process of maintenance and development of their own way of life is progressing slowly due to various structural problems. On the one hand, the results of the land redistribution have only partially satisfied the demands of the Guaraní people. On the other hand, many communities do not have sufficient productive resources at their command to ensure their economic integration into the regional market and are, thereby, obliged to continue working for the estate owners on a temporary basis, which impedes the definitive rupture of their relationship with the oppressors. This situation is especially challenging for the inhabitants of the recently created settlements, who, among other problems, have to face the lack of food safety and precarious living conditions. It is worth pointing out 
that, as a result of the procedure of clearing title, various non-indigenous third parties have preserved their rights to land properties within the area of the indigenous Community Lands of Origin. Their presence affects the ability of the Guaraní to exercise autonomy over their territory. As a consequence, there are still Guaraní who continue to live on the various estates of the Chaco, a situation which prevents them from sustaining a relationship with the other free communities, reproducing their culture and exercising their rights to self determination (CEJIS 2011a).

According to the study conducted by the Centro de Estudios Jurídicos e Investigación Social (CEJIS) in 13 out of 17 communities from the Alto Parapeti Community Land of Origin, there are approximately 47 Guaraní who live and work permanently on the estates located in the zone. There is also a significant number of Guaraní who perform work on a temporary basis for one or various bosses. The size of this seasonal workforce population fluctuates between 153 and 253 individuals. According to the testimonies received during the research, in most cases the employment relationship is characterized by the overexploitation of the family labor power which is expressed in the labor of the wife and children as a part of the worker's agreement with the estate owner, the lack of a valid contract and social security benefits, and remuneration below the minimum wage (CEJIS 2011a).

The Guaraní workers who live permanently on the estates can freely assist the local community assemblies, however few of them do so due to excessive physical labor, lack of time and because they fear their bosses. The relationship between the estate owners and the Guaraní workers as well as their children is often characterized as a "spiritual compaternity", given that the bosses take part in the first communion and confirmation ceremonies as well as the graduation parties which further strengthens the pattern of domination (Bergier 2011a).

Unfortunately, both the permanent and seasonal workers are, to a certain extent, victims of exclusion and discrimination by members of the free Guaraní communities, and are stigmatized as "those who work for the oppressors" even though they lack other forms of subsistence and are therefore obliged to seek employment from the property owners (Bergier 2011a). During a field research, a Guaraní woman stated the following:

Los que van a trabajar para los patrones nos preguntan: ¿Acaso ustedes nos van a dar si yo no voy a trabajar? Hay discriminación en las comunidades de las personas que trabajan para los patrones. Pero también hay que entender la necesidad. Mi hermano se fue a trabajar 3 días para el patrón y ya empezaron a hablar mal de él los comunarios $^{2}$.

2 "Those who go to work for the bosses ask us: Will you give us food if we don't go to work on the estate? There has been discrimination against the people who work for the bosses. But we 
This situation of external exploitation and internal discrimination poses one of the biggest challenges for the communities who find themselves in the process of reconstructing their cultural identity. Therefore, a complete eradication of all forms of bondage and servitude is essential to ensure a dignified life and a promissory future for the present as well as the future generations of the Guaraní people.

\section{The main components of the Guaraní cultural revitalization process}

Slavery and debt bondage have caused great damage to the Guaraní social tissue as their opportunities of cultural reproduction have been drastically limited in the captive communities. Over many years the Guaraní have been attempting to revive some of their traditional practices as well as to eliminate the practices associated with the way of life of the bosses.

Wallace defines the concept of revitalization as "a deliberate, organized, conscious effort by members of a society to construct a more satisfying culture" (Wallace 1956: 256). When speaking of the Guaraní sense of cultural identity and its empowerment, there are various components which need to be taken into account. Here I will briefly summarize four of the revitalization demands which have been expressed by the Guaraní people: territorial management, customary law (community justice), preservation of the langu-age and the inclusion of the Guaraní women in the decisionmaking process.

As far as the revitalization of the Guaraní culture is concerned, territorial management is one of the crucial elements involved. The exercise of the right to self-determination means, above all, the defense and control of the Guaraní ancestral territory of which they were dispossessed by the Spanish invaders. Currently, this process poses many challenges and, at the same time, constitutes a manner of re-affirming the culture and the collective right of the original peoples to exist and defend their identity in front of a society that is excluding in many cases.

The land is perceived as a sacred space which enables the Guaraní to practice their spirituality and live according to the vision of $I y a m b a e^{3}$ - one of the most essential principles which shapes their culture - and thus to work freely in their own territory, in opposition to the forced labor which

have to understand their necessity. My brother went to work for the estate owner. He went away only for three days but the community members still talked bad about him". Testimony received by the Centro de Estudios Jurídicos e Investigación Social (CEJIS) during its visit to the community of Colorada in the zone of Alto Parapetí, 8 Dec. 2011.

3 Iyambae means "without owner" in the Guaraní language. 
was imposed on them for more than a century. More fundamentally, the territory is envisioned as a space where the indigenous will be able to exercise their innate right to self government (CEJIS 2011b).

The Guaraní people cannot fully exercise their right to self-determination and territoriality, given that their land continues to be under pressure from the estate owners. This situation brings about many conflicts which are caused by territorial disputes, as the bosses are often reported to transgress the community limits, taking advantage of the natural resources such as wood as well as the pasture areas. These transgressions affect the ability of the community members to practice sustainable agriculture in their plots. In order to resolve the conflicts, the indigenous families and the estate owners come to informal agreements. However, these are rarely fulfilled because the Guaraní lack the capacity to claim their rights in court and are practically defenseless in the event of an infraction. Therefore, the Guaraní territory, perceived as a source of the cultural identity, requires constant control and defense and needs to be permanently reclaimed and reasserted (CEJIS 2011a).

The security and permanence of the territorial management is also threatened by natural resources extraction. There are hydrocarbons exploitation areas in the Alto Parapetí zone as well as in the indigenous territories represented by the Guaraní Captains Council of the Chuquisaca department. The indigenous denounce irregularities in the consultation process which was carried out in their territories as well as the destruction of their habitat which includes water pollution, biodiversity decline and the loss of medicinal plants. This leads the Guaraní to formulate the need to establish a social and ecological monitoring system which could prevent the damage that might be caused by the companies engaged in hydrocarbon extraction. Such system would additionally strengthen their sense of belonging and connection with the land and empower them as legitimate keepers of their territory (CEJIS 2011b).

As far as the linguistic demands are concerned, the competence of bilingualism is strongly valued among the Guaraní. The ability to speak both languages - Guaraní and Spanish - appears to be one of the principal social assets; however the members of the free communities are concerned about the gradual loss of their native language, especially among the younger generation (CEJIS 2011b).

The Bolivian Guaraní people is made up of a population of approximately 125.159 persons, who live mainly in the province of Cordillera in the Santa Cruz department, the province $\mathrm{O}^{\prime}$ Connor in the Tarija department and the provinces Luis Calvo and Eduardo Siles in the Chuquisaca department. Currently, there are approximately 43.700 Guaraní native speakers, taking 
into account the population over the age of of $5.6,24 \%$ of the population is monolingual in Guaraní, whereas 56.53 per cent are monolingual Spanish speakers. The rest of the population is bilingual in Guaraní and Spanish (38.27 per cent) (Lopez \& Censabella 2009: 197).

The Political Constitution of the State establishes the right of the original indigenous peasant nations and peoples to an intra-cultural, inter-cultural and multi-lingual education in the whole education system (Art. 30 II-12). Nevertheless, access to bilingual education in the rural areas is still very limited. As far as the Alto Parapetí territory is concerned, although Guaraní is spoken in the majority of the settlements, some of the inhabitants are reported not to have an active command of the language. When it comes to children's instruction at school, the situation seems to be highly distressful as most of the communities lack bilingual teachers (CEJIS 2011a).

The case of one community is especially worth pointing out, given that the majority of its younger members cannot speak their native language, due to the forced displacement to urban areas to which they were subjected in their early childhood. The youngsters were separated from their families and forced to work as servants in a nearby city, thus gradually losing their ability to speak their mother tongue. According to the testimonies gathered in the zone, forced relocation of the Guaraní workforce from rural to urban areas was commonly practiced by the estate owners (CEJIS 2011a). One of the young people recounted these painful experiences:

Nosotros, los jóvenes que estuvimos trabajando en la ciudad ya no sabemos el idioma Guaraní. Cuando vamos a la comunidad, escuchamos, pero necesitamos que alguien nos traduzca. Gracias a dios logré hablar con mi abuelo. Unos tiempitos me estaba enseñando pero luego ya falleció. Unos diez niños los trajeron a la ciudad forzosamente. Algunos jóvenes salieron maestros pero no es lo mismo cuando uno nace en el idioma. Cuando uno de grande aprende es distinto ${ }^{4}$.

As the extent of psychological violence inflicted on the Guaraní is gradually revealed, a need for a locally developed curriculum which would value both their language and their culture becomes more and more urgent:

The bosses were even capable of doing away with the cultural self-esteem of the Guaraní indigenous people, introducing into their subconscious concepts

\footnotetext{
4 "We, the young people who were working in the city, don't know the Guaraní language anymore. When we go to a community we listen but we need somebody to translate it for us. Thank god I managed to talk with my grandfather. He had been teaching me for some time but then he died. They brought ten children to the city by force. Some of the youngsters became teachers but it's not the same when somebody is born into the language. When somebody learns as an adult it's different". Testimony received by the Centro de Estudios Jurídicos e Investigación Social (CEJIS) during its visit to Camiri. June 2011.
} 
undervaluing themselves as lazy, vice-ridden (alcoholic, coca consumers), incapable of surviving without the boss (IACHR 2009: 25).

The testimonies collected in the indigenous territories confirm that it is also essential for the curriculum to include the history of the Guaraní struggle for self-determination. A woman from the community of Itakise explained how the Guaraní are encouraged to forget their past and the human rights violations they were subjected to:

Un licenciado nos decía que no deberíamos hablar de los patrones porque nosotros ya somos libres. Nosotras hemos sufrido mucho, pero los que no han sufrido no quieren escuchar nuestras historias, no quieren escuchar de cómo teníamos nuestro sueño de liberación. ¿Porque no quieren que hablemos de patrones? Ese dolor es para mi, allá se ha muerto mi abuelito. Para mi es importante hablar de eso, tantos años que han sufrido mi mama y mi abuela, por eso es muy importante ${ }^{5}$.

Another valuable cultural component of the Guaraní ancestral society which needs to be revived is the customary law (community justice), applied according to a set of values which traditionally ruled their community life:

Para conseguir la autodeterminación necesitamos recuperar la sabiduría de nuestros antepasados como mboroaiu- vivir en armonía, estar unidos. También mantener el ñandé rekó- la forma que somos. Hemos perdido nuestros usos y costumbres, ya no hay el arete guasu, que significa invitar a toda la comunidad. Otro problema es que la ciencia va avanzando y cambiando la situación. Y nos trae otro pensamiento, se pierde la costumbre, el idioma ${ }^{6}$.

For many years, the Guaraní people have lived under a threat of physical violence and have been often subjected to violent punishments for their "disobedience". The punishments involved lashings, burning of their crops and killing of their animals by the estate owners (IACHR 2009: 31). One of

\footnotetext{
5 "A professor has been telling us that we shouldn't talk about the estate owners anymore because we are free now. We have suffered a lot, but those who haven't suffered don't want to hear our stories, they don't want to hear about how we used to have our dream of liberation. Why don't they want us to talk about the bosses? This is my pain, my grandma died out there. For me it is important to talk about this, so many years they have suffered- my mother and my grandmother, that's why it is so important". Testimony received by the Centro de Estudios Jurídicos e Investigación Social (CEJIS) during its visit in the community of Itakise. Dec.2010.

6 "In order to obtain self-determination we need to regain the wisdom of our ancestors like mboroaiu- live in harmony, be united. Also, to keep ñandé rekó- the way we are. We have lost our uses and customs, there's no arete guasu anymore, which means "to invite the whole community". Another problem is that science has been progressing and changing the situation. It already brings another way of thinking, we lose our custom, and our language". Testimony received by the Centro de Estudios Jurídicos e Investigación Social (CEJIS) during its visit to the community of Iviyeka in the zone of Alto Parapetí, 8 Dec. 2011.
} 
the most common torture methods used by the oppressors was the cepo. The estate owners would tie the "offenders" to a post and flog them (CEJIS 2011b).

The indigenous intend to recreate their customary law in opposition to these infrahuman and degrading practices which they consider "savage" and "irrational". The cultural loss might be reversed by constructing an indigenous jurisdiction with a considerable degree of independence from the ordinary justice system, which has little regard for the community life where the rights of the collective prevail over the rights of the individual. The administration of justice should therefore rely on the wisdom and authority of the elders, as well as the political power of Mburuvisas, with the supervision of the community assembly (CEJIS 2011b).

The community justice that the Guaraní aspire to can be characterized as highly restorative, as it aims at repairing harm which was brought upon the community by the offender. It values dialogue and excludes physical aggression and threats. It respects both the physical and moral integrity of the members of the collective, and its primary objective is to address everyday problems which occur in the communities. These values should be transmitted to the younger generation by means of training programmes and educational activities. The problem-solving measures should include work assignments, warnings and payment of fines. It is only in the case of chronic and more serious offenders that the expulsion from the community is justified (CEJIS 2011b). Nevertheless, identification with the former practices imposed by the estate owners can still be observed, as some community members fail to recognize the difference between their own traditions and violent practices inflicted by the bosses:

Lo que sé de justicia comunitaria es por mis abuelos que contaban como se castigaba con el cepo ${ }^{7}$.

One of the growing demands with regard to cultural resurgence is related to the inclusion of women in the decision making process in the Guaraní territory. It should be highlighted that the situation of women in the captive communities was highly distressful, as they had to endure multiple forms of abuse and suffered discrimination not only on the basis of their ethnic origin but also on the basis of gender. Apart from the forced labor on the estates, which far exceeded their physical abilities, they were often raped and sexually assaulted. The children who were born as a result of sexual abuse inflicted on the Guaraní women by the estate owners, legitimized and

\footnotetext{
"What I know about the community justice is from my grandparents who used to tell me how he people were punished with the cepo". Testimony received by the Centro de Estudios Jurídicos e Investigación Social (CEJIS) during its visit to the community of Iviyeka in the zone of Alto Parapetí, 8 Dec. 2011.
} 
supported the servitude regime and the blood ties between the victims and their oppressors, strengthened the bosses' dominance (Bergier 2011b).

Nowadays the Guaraní women who live in the free communities continue to suffer discrimination in many aspects of their everyday life. Chirix and Kachikel observe the "triple oppression" faced by indigenous women due to different domination systems which affect them:

1. A domination system which legitimizes the binary systems to maintain the relations of power between men and women,

2. An internal colonialism which maintains the social hierarchy,

3. The neo-liberal system which legitimizes the asymmetric relations of power between race and class and which promotes exclusion, marginalization and segregation, and exacerbates poverty (Chirix \& Kachikel 2011).

Among the Guaraní, these basic inequalities are expressed in the division of the household labor, which often impedes women from actively participating in the local assemblies, thus preventing them from taking part in the decision making process. The women themselves often accept the traditional gender roles and the subordinate status imposed on them by the estate owners and perpetuated by the patriarchal organizational structure within their communities. Many of them do not aspire to access the decision making power in the capitanías. When asked about their personal plans, they place the importance of generating family income and providing new sustainable patterns of farming production in the communities above any other personal interests (Bergier 2011b).

Nevertheless, the birth of a new gender consciousness among the Guaraní women can also be detected. During a study conducted in the communities of Alto Parapetí and in the zones represented by the Council of the Guarani Captains of Chuquisaca (Consejo de Capitanes Guaraníes de Chuquisaca), the Guaraní women have voiced their concerns regarding equal access to and full participation in power structures within the indigenous selfgovernment. They have also stated their intention to reclaim their social and cultural identity by obtaining positions within the political and representative system. However, due to the persistence of patriarchy, the change of mentality seems to have a rather high social cost. According to the information collected during the study, many women have to ask their husband's permission in order to take part in local assemblies, courses and training programmes. Such requests often generate conflicts between the spouses that can even lead to domestic violence (Bergier 2011b).

At present, there are a number of Guaraní women who hold positions at community level, however few of them access superior positions within the 
indigenous organizational structure at the level of capitanías and achieve representation in public governance. Nevertheless, there are five Guaraní women who hold public offices in the department of Chuquisaca: two substitute members of the Departmental Legislative Assembly and three municipal councilors (Bergier 2011b).

Although Guaraní women seldom access executive decision-making authority, a shift in gender role perception has already occurred, which can be reflected in the words of Justa Cabrera, one of the most important Guaraní leaders and a former president of the National Confederation of Indigenous Women of Bolivia:

En estos últimos tiempos estamos trabajando con miradas al poder. Cuando se trabajaba proyectos normativos para las mujeres, se las ponían a hacer artesanías, bordados, etc. Ahora estamos trabajando para ser autónomas, autogestionarias de nuestros recursos. Ejercer derecho de participación con poder económico y político ${ }^{8}$.

\section{Preserving the way of life of the Guaraní people: the need for Government assistance}

The reconstitution of significant parts of the Guaraní ancestral territory was a milestone which undoubtedly enabled considerable progress regarding the improvement of the Guaraní living conditions and their cultural revitalization. This situation has opened new possibilities for the communities to reproduce their traditional practices and to live a dignified life. However, the indigenous still face numerous obstacles when they struggle to maintain their cultural and linguistic distinctiveness, while remaining in the vicinity of their long time oppressors. Given that many of these difficulties are caused by structural problems such as the inefficiency of the land redistribution process, including the lack of land quality which affects the agricultural productivity of the Guaraní communities, long term state assistance is desperately needed.

Furthermore, it should be highlighted that there are certain demands of the Guaraní which need to be addressed as soon as possible to create dignified conditions for their social, cultural and economic reproduction. One of these priorities is the access to justice and reparation. Therefore, certain

\footnotetext{
8 "Recently, we have been working toward a vision of power. When the draft legislation on women was being elaborated, they were put aside to embroider and make handicrafts, etc. Now we are working to be autonomous and to self-manage our resources. To exercise the right to participate with economic and political power". Lecture presented during a workshop on gender and indigenous peoples in Centro de Estudios Juridicos y Sociales (CEJIS). Santa Cruz de la Sierra, Bolivia. April 2011.
} 
actions must be undertaken and these include prosecution and punishment of the individuals and groups who are responsible for unspeakable crimes and acts of violence against the members of the captive communities. More fundamentally, the state authorities should ensure that economic reparations are provided for the victims.

It can be observed that although state intervention marked the beginning of a new era in the process of the liberation of the captive communities, the Guaraní people still confront human rights violations which range from work relations that are not in line with the law to the extreme of servitude. The territorial reconstitution of the Guaraní cannot be considered a sufficient solution as long as it is not accompanied by measures that safeguard their human rights and enable their reproduction in the social, cultural, economic and political dimension. These measures should essentially include economic support in the area of agriculture, which needs to be provided especially to new settlements, so as to guarantee their long-term independence from the bosses. The above mentioned actions ought to be followed by a true implementation of an inter-cultural and multilingual education policy in the rural communities, in keeping with their customs and traditions. Last but not least, a constant presence of labor and judicial authorities in the region is required in order to prevent and monitor any criminal activities of the estate owners that might occur.

\section{References}

Bergier A.

(2011a) "Familias empatronadas en la zona de Alto Parapeti: la lucha por la liberación definitiva", Observatorio de Derechos Humanos y Conflictos Socioambientales, 6 October, retrieved 28 January 2013: http://observatorioddhh.blogspot.com/2011/10/familias-empatronadas-en-la-zona-de.html.

(2011b) Relatos de las mujeres cautivas: luchando por la libertad del pueblo Guaraní, CEJIS, unpublished manuscript.

Centro de Estudios Jurídicos e Investigación Social (CEJIS)

(2011a) Base de datos sobre la servidumbre, conflictos y el proceso de reconstitución territorial del pueblo Guaraní de la Capitanía de Alto Parapetí, unpublished manuscript.

(2011b) Diagnóstico de identificación de capacidades de formación socio-política en el Consejo de Capitanes Guaraníes de Chuquisaca (CCCH) y la Capitanía de Alto Parapetí (CAP), unpublished manuscript.

(2012) Reconstitución territorial del pueblo guaraní de Chuquisaca y Santa Cruz de la Sierra, unpublished manuscript.

Chirix O., Kachikel M.

(2011) "Género, una mirada crítica y reflexiva: experiencias de lucha por los derechos individuales y colectivos de las mujeres indígenas", 20 June, retrieved 28 
January 2013: http://observatorio-derechosindigenas.blogspot.com/2011/06/generouna-mirada-critica-y-reflexiva.html.

Égido I., Bergier A.

(2010) Estado de situación de los derechos de los pueblos indígenas en Bolivia, La Paz. Inter-American Commission on Human Rights (IACHR)

(2009) Captive Communities: Situation of the Guarani Indigenous Peoples and Contemporary Forms of Slavery in the Bolivian Chaco.

International Labour Organization

(2005) Enganche y Servidumbre por Deudas en Bolivia, Ginebra.

Lopez L.E., Censabella M.

(2009) Bolivia en el Chaco y en el Oriente, [in:] I. Sichre (ed.), Atlas Sociolingüístico de pueblos indígenas en América Latina, Cochabamba.

Ombudsman of Bolivia, Ministry of Justice, Indigenous Peoples and Empowerment, $\mathrm{CCCH}$.

(2006) Aipota aiko chepiaguive cheyambae (Quiero ser libre, sin dueño), La Paz.

Pifarré F.

(1989) Los Guaraní Chiriguano. Historia de un pueblo, tomo 2, La Paz.

The Political Constitution of the Plurinational State of Bolivia (2009)

Stavenhagen R.

(2009) Report of the Special Rapporteur on the Situation of Human Rights and Fundamental Freedoms of Indigenous People. Mission to Bolivia.

United Nations Permanent Forum on Indigenous Issues

(2009) Mission to Bolivia. Report and Recommendations.

Wallace A.

(1956) "Revitalization movements", American Anthropologist, vol. 58, no. 2., April, pp. 264-281, retrieved 28 January 2013: JSTOR database.

\section{Współczesne niewolnictwo i walka o autodeterminację: casus kultury Guaraní z boliwijskiego Chaco}

Przez ponad stulecie boliwijscy Indianie Guaraní byli przedmiotem nieludzkiego traktowania $\mathrm{z}$ powodu praktyk takich jak niewolnictwo, praca przymusowa oraz poddaństwo. Reformy agrarne, których celem była redystrybucja władzy ekonomicznej i społecznej, skoncentrowanej w rękach niewielkiej regionalnej elity, spowodowały zmianę w polityce rządowej, gwarantując dostęp ludów tubylczych do kolektywnej własności ziemi. Proces ten umożliwił przedstawicielom kultury Guaraní zerwanie zależności wynikających z systemu pracy przymusowej i więzienia za długi.

Niniejszy artykuł jest poświęcony obecnej sytuacji Indian Guaraní, a w szczególności zmianom i wyzwaniom, którym muszą stawić czoło w związku z uzyskaniem tytułów własności ziemi oraz częściową odbudową utraconego terytorium. Omówione zostały aktualne dane związane $\mathrm{z}$ walką o ponowne zdefiniowanie i odbudowanie kulturowej tożsamości tej grupy, jak również specyficzne elementy kulturowe, uważa- 
ne za wartościowe przez społeczność Guaraní, w tym zarządzanie terytorialne, język ojczysty, prawo zwyczajowe oraz szerszy udział kobiet w strukturach decyzyjnych ruchu indiańskiego.

\section{Contemporary Slavery and the Struggle for Self-Determination: The Case of the Guaraní People from the Bolivian Chaco}

For over a century, the Bolivian Guaraní people have been subjected to infrahuman treatment which involved practices such as slavery, forced labor and servitude. The new agrarian legislation, aimed at reversing the concentration of the economic and social power in the hands of a small regional elite, represented a shift in a state policy, facilitating the access of indigenous peoples to collective land property and thereby enabling them to break away from the conditions of debt bondage and forced labor.

The article examines the current situation of the Guaraní and focuses on the changes and challenges that have been introduced to their way of life due to the implementation of the clearing title process which brought about a partial reconstitution of their territory. It presents the recent data on their struggle to redefine and reconstruct their cultural identity and places emphasis on specific cultural elements considered valuable by the Guaraní society: territorial management, native language, customary law and wider inclusion of women in decision-making structures within the indigenous political organization.

Key words: Guaraní people, rights of indigenous peoples, contemporary forms of slavery, cultural revitalization 